\title{
Sensory Analysis, Caffeine, Chlorogenic Acid and Non-Volatile Taste Compounds of Arabica Coffee (Coffea arabica) Fermented with Sugar Addition for Brew Taste
}

\author{
Kresna Mulya Santosa ${ }^{1}$, Supriyadi ${ }^{*}$, Sri Anggrahini ${ }^{1} \&$ Yudi Rahmadian
}

\author{
${ }^{1}$ Department of Food Science and Technology, Faculty of Agricultural Technology \\ Universitas Gadjah Mada, Jl. Flora No.1 Bulaksumur, Yogyakarta 55281 Indonesia \\ ${ }^{*}$ Corresponding Email: suprif248@ugm.ac.id
}

\begin{abstract}
Arabica coffee is the most popular variety of coffee among the people because it has a more complex flavor than other coffee varieties. This study aims to determine sensory properties and non-volatile components in Arabica coffee fermented with sugar addition. The sensory assessment showed that the best cupping score was the samples fermented with the addition of $0.55 \%$ fructose with a total score of 85.25 compared to honey $(\mathrm{H})$ and Fullwash (FW) samples. Fermentation with the addition of $0.55 \%$ fructose could produce better coffee compared to samples $(\mathrm{H})$ and $(\mathrm{FW})$. Fermentation with the sugar addition of $0.55 \%$ could affect non-volatile components such as soluble sugars, organic acids, amino acids, caffeine, and chlorogenic acid. The content of chlorogenic acid and caffeine analysed by HPLC was found relatively stable in green and roasted beans. Amino acids analysed by LCMS showed glutamate was the highest amino acid in all samples and were supposed to have a role in Maillard reaction contributing to coffee flavor. In conclusion, fermentation with the addition of $0.55 \%$ sugar in coffee processing could generally enhance the coffee flavor for brew taste with its potential as functional drink.
\end{abstract}

Keywords: Arabica coffee, sugar fermentation, sensory attributes, non-volatile compounds, coffee flavour

\section{INTRODUCTION}

Aroma and taste are the coffee brewed's main character, which formed from a series of post-harvest processing. High-quality coffee flavor is described as a pleasant sensation from the combination of balance between flavor, body, and aroma with no flavor defects such as over-fermented, earthy, and oily (Mori et al., 2003). The aroma and taste of coffee are the combinations of several constituents of volatile chemicals such as acids, aldehydes, ketones, and phenolic compounds with nonvolatile components such as sugars, proteins, amino acids, organic acids, and caffeine (Lee et al., 2015). Volatile and non-volatile compounds of coffee are influenced by coffee varieties, regions, processing methods, levels of roasting, grinding size, and brewing method (Illy and Viani, 2005). Among the processing methods, the fermentation process is the most influential stage in the formation of coffee flavors (Bressani, 2018; Yusianto and Widyotomo, 2013).

The fermentation process is one step in the wet processing of coffee beans. It contributes to forming precursor compounds of flavors such as organic acids, amino acids and reducing sugars. The process not only degrades the mucilage layer, but also occurs a chemical process that is useful in the character and flavor formation of the coffee. (Avvallone et al., 2001; Jackels et al., 2006; Lin, 2010). Uncontrolled fermentation can damage the coffee flavor, due to the growth of microorganisms that naturally exist on the surface of the coffee fruit (FAO, 2004). Previous experiments have been done by Bressani (2018) with adding the yeast starter in the fermentation process of the Arabica coffee (Caturai Amarelo). The addition of a starter is done by directly into the fermentation tank. The differences in the treatment of this starter gave different results. The analysis showed an increase of organic acids in samples treated with the starter addition in the fermentation tank, and it correlated with the sensory value of coffee based on the Specialty Coffee Association of America (SCAA) cupping quality classification.

Wet coffee processing had higher acid content, but the sugar content is lower than the dry processing (Duarte et al., 2010; Knopp et al., 2005). The content of sugars in coffee beans affects the production of non-volatile compounds as precursors of coffee flavor. Several attempts have been made by farmers to improve the quality of coffee beans. One of the efforts carried out by using juice as fermentation believed to increase the content of sugars and organic acids correlated to coffee's sensory value. Low sugar content in the wet-processed coffee may be enhanced by adding sugar during the fermentation process. However, it is also unclear what kind of added sugars can contribute to the coffee sensory.

One of flavor formation is through the Maillard reaction. Wong et al. (2008) concluded that the Maillard reaction is a reaction of specific amino acids and reducing sugars producing the flavor of caramel, fruity, and flowery. Dorfner et al. (2003) and Bytof et al. (2005) stated that sucrose could contribute in the formation of flavor and color in coffee through a caramelization process after the roasting process. Given the importance of the sugar compounds in the formation of coffee flavor, it is necessary to study the addition of sugars during fermentation. The purpose of this research was to study the effect of the addition of glucose, fructose, and sucrose with a different concentration level during the fermentation process to non-volatile taste compounds as precursors of developing coffee flavor. The results of this research are considered useful for developing the wet processing coffee to enhance the quality of the coffee flavor for brew taste. 


\section{MATERIALS AND METHODS}

\section{Materials}

Arabica coffee Cherries were generated from Matt Husen Andungsari Coffee Plantation, Bondowoso Ijen - East Java Indonesia, located at an altitude of 1,400 meters above the sea level. D-fructose, D-glucose, Sucrose, aquapro (HPLC Grade) and O-phthalaldehyde (OPA) were obtained from Merck (Germany). Standard organic acids (citric, acetic, lactic, malic, succinic, propionic and butyric) were generated from Merck (Germany). Standard amino acids (l-alanine, 1-arginine hydrochloride, 1-aspartic, 1-cysteine, l-glutamic acid, l-glycine, 1-histidine monohydrochloride monohydrate, 1-leucine, l-isoleucine, l-lysine monohydrochloride, l-methionine, 1-phenylalanine, 1-proline, l-serine, 1-threonine, l-tyrosine, tryptophan and l-valine) were obtained from Sigma-Aldrich (USA). Caffeine and chlorogenic acid were also obtained from Sigma-Aldrich (USA) and all other chemicals and reagents used were pro analysis and analytical grades.

\section{Sample Preparation}

Coffea arabica beans were harvested from selected cherries and then soaked for 12 hours. After that, the coffee beans were pulped using a vis-pulper (Honda GX 160-5.5 HP, Indonesia). Depulped coffee beans (no later than 2 hours) were added with D-fructose, D-glucose and sucrose at the concentration of $0.55 \%, 1.1 \%$ and $1.65 \%$, respectively while honey and fullwash beans were without any addition sugars. A total of $2.5 \mathrm{~kg}$ of beans were then put into perforated plastic bags with a thickness of $0.5 \mathrm{~mm}$ and a length of $90 \mathrm{~cm}$ and fermented for 24 hours. After fermentation, the coffee beans were washed thoroughly, then dried in the sun until the moisture content $12 \%$. The bean skin was then peeled using a huller machine (LM24$2 \mathrm{C}$, China) until a green bean was obtained.

\section{Roasting and Milling of Coffee Beans}

Green beans $(1 \mathrm{~kg}$ ) were roasted using a machine (William Edison W600) following the method of Baggenstoss et al. (2008). The roasting process was done at a high temperature for a short time. Roasting temperature was set at $200-210^{\circ} \mathrm{C}$ and maintained for 18 minutes. Then, the roasted beans were cooled for 5 minutes and stored in the airtight containers. For the milling process, the roasted beans were ground using a grinder (Latina N-600) and sieved using a sieve size of 20 mesh and then stored in a vacuum packaging.

\section{Brewing and Sensory Analysis}

A total of $8.25 \mathrm{~g}$ of coffee powder was brewed with 150 $\mathrm{mL}$ of hot water temp $\left(93^{\circ} \mathrm{C}\right)$ for $4 \mathrm{~min}$. Each unit of experiment was repeated five times, presented in five bowls to test the uniformity. Descriptive analysis was conducted, including in three steps: i) evaluation of coffee aroma by sniffing the dry powder, ii) evaluation of the aroma by sniffing a drink in 3 min after brewing, and iii) 8-10 min after brewing. Sensory analysis was performed by three panelists from Gayo Cupper Team of Nangroe Aceh Darussalam, Indonesia. The assessment used was a system developed by Specialty Coffee Association of America (SCAA, 2009), by giving a score between 1-10 on each variable tested. Score 1 was the lowest score and 10 was the highest score.

\section{Analysis of Organic Acids}

Analysis of organic acids refers to the method (Ribeiro et al., 2017), coffee powder ( $3 \mathrm{~g}$ ) was added with $20 \mathrm{~mL}$ distilled water at the room temperature. The sample was homogenized for $10 \mathrm{~min}$ using a magnetic stirrer and filtered using a whatmann no. 3 filter paper. The extract was centrifuged at $10.000 \mathrm{rpm}, 4{ }^{\circ} \mathrm{C}$ for $10 \mathrm{~min}$. Supernatant was regulated to achieve a $\mathrm{pH}$ of 2.11 using a perchloric acid solution $(200 \mu \mathrm{M})$ before a second centrifugation under the same condition. The second supernatant was filtered using a cellulose acetate filter $(0.22 \mu \mathrm{m})$ prior to analysis by HPLC system. The organic acids was determined by the HPLC system (ShimadzuRF-10AXL) equipped with C18 column $(7.9 \mathrm{~mm}$ x $30 \mathrm{~cm})$. The mobile phase used was 100 $\mu \mathrm{M}$ of perchloric acid solution and the flow rate of $0.6 \mathrm{~mL} /$ $\min$. The column temperature was maintained at $50{ }^{\circ} \mathrm{C}$. The detection of organic acids was read by using a wavelength of $210 \mathrm{~nm}$. Identification and quantification were done by comparing to calibration curve of standards compounds.

\section{Sugar Analysis}

Analysis of soluble sugars refers to the method (Ribeiro et al., 2017), $10 \mathrm{~g}$ of coffee powder was added with $50 \mathrm{~mL}$ of distilled water and extracted in the ambient temperature for 10 min using a magnetic stirrer. The extract was centrifuged at $10.000 \mathrm{rpm}, 4^{\circ} \mathrm{C}$ for $10 \mathrm{~min}$. Supernatant was regulated to achieve a $\mathrm{pH}$ of 2.11 using $200 \mu \mathrm{M}$ perchloric acid solution and then centrifuged again with the same condition. The supernatant was filtered by a cellulose acetate filter $0.45 \mu \mathrm{m}$ prior to analysis by HPLC. HPLC system (Shimadzu SCL-10A) was equipped with Restek columns Finnacle II Amino $5 \mu \mathrm{m}(150 \times 4.6 \mathrm{~mm})$ to determine the soluble sugars. $100 \mu \mathrm{M}$ solution of perchloric acid was used as the mobile phase with a flow rate of $0.6 \mathrm{~mL} / \mathrm{min}$. The column temperature was maintained at $40{ }^{\circ} \mathrm{C}$ and detected by a Refractive Index Detector (RID). Standard sugar solution was used for confirmation purposes and determining the concentration of the sugar compounds being analysed.

\section{Analysis of Amino Acids}

Sample preparation for testing amino acids referred to the Perwita (2016) method. Samples (1 g) and $2 \mathrm{ml}$ of $\mathrm{HCl} 6 \mathrm{~N}$ in glass tubes were homogenized using a vortex. Hydrolysis was done by using an oven at $110{ }^{\circ} \mathrm{C}$ for 24 hours, then cooled and neutralized with $\mathrm{NaOH} 6 \mathrm{~N}$. A mixture of 2.5 $\mathrm{mL}$ of $40 \%$ lead acetate and $1 \mathrm{~mL}$ of $15 \%$ oxalic acid was added to each sample before being transferred to a $100 \mathrm{~mL}$ flask and added distilled water to the mark. $3 \mathrm{~mL}$ of the sample was filtered using a nylon syringe filter Millex 0.45 $\mu \mathrm{m}$ and then dilution was applied for 5 times. Samples were treated for $1 \mathrm{~min}$ in OPA solution $(5 \mathrm{~mL}$ sample added 25 $\mathrm{mL}$ OPA). The samples were injected into the HPLC as much as $5 \mathrm{~mL}$. Amino acid analysis refers to the method (Bytof and Peter, 2005) using the HPLC system (CBM 20A). The column used was a column (ODS-2 Thermo 
Scientific Hyersil). Buffer A consisting of $2 \mathrm{~g}$ Na-acetate (pH 6.5), $0.5 \mathrm{~g}$ of Na-EDTA, $90 \mathrm{~mL}$ of methanol and $15 \mathrm{ml}$ of THF was dissolved in 1L of distilled water and filtered using a $0.45 \mu \mathrm{m}$ milipore paper and stored in dark bottles. Buffer B (95\% methanol) was filtered use paper milipore $0.45 \mu \mathrm{m}$. The flow rate at $1 \mathrm{~mL} / \mathrm{min}$. The detector used was a fluorescence detector. Identification and quantification of amino acids were done by comparing the retention time, in line with a specific spectrum of authentic amino acid standards (Sigma-Aldrich).

\section{Analysis of Caffeine and Chlorogenic Acid}

Analysis of caffeine and chlorogenic acid referred to de Maria et al. (1995) methods. Coffee powder (0.2 g) was dissolved in $60 \mathrm{~mL}$ of boiling water, then shaken at room temperature for $15 \mathrm{~min}$ at $300 \mathrm{rpm}$. The mixture was filtered using filter paper (Whatman no. 1) and washed using 30 $\mathrm{mL}$ of distilled water. The filtrate was added with $2 \mathrm{~mL}$ of saturated lead acetate and the final volume was made with distilled water to $100 \mathrm{~mL}$. Colloid dispersion was then filtered using $4 \mathrm{~mm}$ PTFE syringe filter of $0.45 \mu \mathrm{m}$ prior to analysis.

Caffeine and chlorogenic acid were analyzed using LCMS with a $\mathrm{C} 18$ column $(5 \mu \mathrm{m} 4.6 \times 150 \mathrm{~mm})$ and mobile phase $\mathrm{A}$ $\left(0.3 \%\right.$ formic acid in $\left.\mathrm{H}_{2} \mathrm{O}\right)$ and mobile phase $\mathrm{B}$ (methanol). The elution gradient was set as follows: $15 \% \mathrm{~B}$ to $28 \% \mathrm{~B}$ in 10 minutes; $28 \% \mathrm{~B}$ to $30 \% \mathrm{~B}$ in 15 minutes; $30 \% \mathrm{~B}$ to $100 \%$ B in 3 minutes; $100 \%$ B maintained within 2 min and $100 \%$ B to $5 \% \mathrm{~B}$ in 5 minutes. The analysis time for $35 \mathrm{~min}$ at a flow rate of $0.2 \mathrm{~mL} / \mathrm{min}$. The injection volume was 5 $\mathrm{mL}$ with detector MS (LCMS-2020), an auto-sampler (SIL-
20A), column oven (CTO-20A), pump (LC-20).

\section{Statistical Analysis}

Statistical analysis was performed using SPSS Statistics 21 (IBM, Chicago, USA). The data were summarized as means \pm standard deviation (SD) and all results were in triplicate experiments. One-way analysis of variance (ANOVA) was performed and the statistical significance of differences $(p<0.05)$ was evaluated and followed by Duncan's multiple range test (DMRT).

\section{RESULTS AND DISCUSSION}

\section{Quality Flavor}

Organoleptic assessments with the the SCAAmethod consist of 11 parameters such as aroma, flavor, aftertaste, acidity, body, balance, sweetness, clean-up, uniformity, overall and total score. Based on the cupping score (Table 1) Samples treated with fructose $0.55 \%(\mathrm{~F}-0.55)$ had the highest score of 85.25, while the Honey $(\mathrm{H}) 83.00$ and Fullwash (FW) 84.50. Sample (F-0.55) had the characteristic aroma of spicy, fruity, tammarine, blackcurrant, grape, grassy, floral, brown dry tea leaf like and molasses. Sample (F0.55) also had the characteristic tastes of spicy flavor, dry fruit, tammarine, blackcurrant, syrup, like tea, floral, tarty, dry berries, honey, salty, medium to light body and light acidity. Samples with the highest score (F-0.55\%) were selected for the next analysis consisting of proximate compotition, organic acids, sugars, amino acids, caffeine and chlorogenic acid that was compared with the samples Honey $(\mathrm{H})$ and Fullwash (FW).

Table 1. Cupping Score of Coffee Fermentation using Different Types of Sugar compared to Honey and Fullwash

\begin{tabular}{|c|c|c|c|c|c|c|c|c|c|c|c|}
\hline \multirow{4}{*}{ Parameter } & \multicolumn{11}{|c|}{ Treatment } \\
\hline & \multirow{2}{*}{\multicolumn{3}{|c|}{$\frac{\text { Fructose }(\mathrm{F})}{\text { Concentration }}$}} & \multirow{2}{*}{\multicolumn{3}{|c|}{$\begin{array}{l}\text { Glucose }(\mathrm{G}) \\
\text { Concentration }\end{array}$}} & \multirow{2}{*}{\multicolumn{3}{|c|}{$\frac{\text { Sucrose (S) }}{\text { Concentration }}$}} & \multirow{3}{*}{$\begin{array}{l}\text { Honey } \\
(\mathrm{H})\end{array}$} & \multirow{3}{*}{$\begin{array}{c}\text { Fullwash } \\
\text { (FW) }\end{array}$} \\
\hline & & & & & & & & & & & \\
\hline & 0.55 & 1.1 & 1.65 & 0.55 & 1.1 & 1.65 & 0.55 & 1.1 & 1.65 & & \\
\hline Aroma & $8.25^{\mathrm{b}}$ & $8.00^{\mathrm{ab}}$ & $8.00^{\mathrm{ab}}$ & $8.00^{\mathrm{ab}}$ & $8.00^{\mathrm{ab}}$ & $8.25^{\mathrm{b}}$ & $8.00^{\mathrm{ab}}$ & $7.75^{\mathrm{a}}$ & $8.00^{\mathrm{ab}}$ & $8.00^{\mathrm{ab}}$ & $8.25^{\mathrm{b}}$ \\
\hline Flavor & $8.00^{\mathrm{a}}$ & $8.00^{\mathrm{a}}$ & $7.75^{\mathrm{a}}$ & $7.75^{\mathrm{a}}$ & $8.00^{\mathrm{a}}$ & $8.00^{\mathrm{a}}$ & $7.75^{\mathrm{a}}$ & $8.00^{\mathrm{a}}$ & $7.75^{\mathrm{a}}$ & $7.75^{\mathrm{a}}$ & $8.00^{\mathrm{a}}$ \\
\hline Aftertaste & $7.75^{b}$ & $7.50^{\mathrm{b}}$ & $7.50^{\mathrm{ab}}$ & $7.50^{\mathrm{ab}}$ & $7.25^{\mathrm{a}}$ & $7.25^{\mathrm{a}}$ & $7.25^{\mathrm{a}}$ & $7.25^{\mathrm{a}}$ & $7.25^{\mathrm{a}}$ & $7.25^{\mathrm{a}}$ & $7.50^{\mathrm{ab}}$ \\
\hline Acidity & $7.75^{\mathrm{b}}$ & $7.25^{\mathrm{a}}$ & $7.25^{\mathrm{a}}$ & $7.25^{\mathrm{a}}$ & $7.25^{\mathrm{a}}$ & $7.25^{\mathrm{a}}$ & $7.25^{\mathrm{a}}$ & $7.25^{\mathrm{a}}$ & $7.25^{\mathrm{a}}$ & $7.25^{\mathrm{a}}$ & $7.50^{\mathrm{ab}}$ \\
\hline Body & $7.75^{\mathrm{b}}$ & $7.75^{\mathrm{b}}$ & $7.75^{\mathrm{b}}$ & $7.75^{\mathrm{b}}$ & $7.75^{\mathrm{b}}$ & $7.75^{\mathrm{b}}$ & $7.75^{\mathrm{b}}$ & $7.75^{\mathrm{b}}$ & $7.75^{\mathrm{b}}$ & $7.25^{\mathrm{a}}$ & $7.75^{\mathrm{b}}$ \\
\hline Balance & $7.75^{\mathrm{a}}$ & $7.50^{\mathrm{a}}$ & $7.50^{\mathrm{a}}$ & $7.75^{\mathrm{a}}$ & $7.50^{\mathrm{a}}$ & $7.50^{\mathrm{a}}$ & $7.50^{\mathrm{a}}$ & $7.50^{\mathrm{a}}$ & $7.50^{\mathrm{a}}$ & $7.75^{\mathrm{a}}$ & $7.50^{\mathrm{a}}$ \\
\hline Uniformity & $10.00^{\mathrm{a}}$ & $10.00^{\mathrm{a}}$ & $10.00^{\mathrm{a}}$ & $10.00^{\mathrm{a}}$ & $10.00^{\mathrm{a}}$ & $10.00^{\mathrm{a}}$ & $10.00^{\mathrm{a}}$ & $10.00^{\mathrm{a}}$ & $10.00^{\mathrm{a}}$ & $10.00^{\mathrm{a}}$ & $10.00^{\mathrm{a}}$ \\
\hline Clean Cup & $10.00^{\mathrm{a}}$ & $10.00^{\mathrm{a}}$ & $10.00^{\mathrm{a}}$ & $10.00^{\mathrm{a}}$ & $10.00^{\mathrm{a}}$ & $10.00^{\mathrm{a}}$ & $10.00^{\mathrm{a}}$ & $10.00^{\mathrm{a}}$ & $10.00^{\mathrm{a}}$ & $10.00^{\mathrm{a}}$ & $10.00^{\mathrm{a}}$ \\
\hline Sweetness & $10.00^{\mathrm{a}}$ & $10.00^{\mathrm{a}}$ & $10.00^{\mathrm{a}}$ & $10.00^{\mathrm{a}}$ & $10.00^{\mathrm{a}}$ & $10.00^{\mathrm{a}}$ & $10.00^{\mathrm{a}}$ & $10.00^{\mathrm{a}}$ & $10.00^{\mathrm{a}}$ & $10.00^{\mathrm{a}}$ & $10.00^{\mathrm{a}}$ \\
\hline Overall & $8.00^{\mathrm{a}}$ & $7.75^{\mathrm{a}}$ & $7.75^{\mathrm{a}}$ & $7.75^{a}$ & $7.75^{\mathrm{a}}$ & $7.75^{\mathrm{a}}$ & $7.75^{\mathrm{a}}$ & $7.75^{\mathrm{a}}$ & $7.75^{\mathrm{a}}$ & $7.75^{\mathrm{a}}$ & $8.00^{\mathrm{a}}$ \\
\hline $\begin{array}{l}\text { Total } \\
\text { Score }\end{array}$ & $85.25^{\mathrm{d}}$ & $83.75^{\mathrm{bc}}$ & $83.50^{\mathrm{b}}$ & $83.75^{\mathrm{bc}}$ & $83.50^{\mathrm{b}}$ & $83.75^{\mathrm{bc}}$ & $83.25^{\mathrm{ab}}$ & $83.25^{\mathrm{ab}}$ & $83.25^{\mathrm{ab}}$ & $83.00^{\mathrm{a}}$ & $84.50^{\mathrm{c}}$ \\
\hline
\end{tabular}

Note: Each value is expressed as an average in SD $(n=3)$. Numbers followed by the same letter in the same line show no significant difference based on the Duncan test $(\mathrm{p}<0.05)$

Sample $(\mathrm{H})$ had a characteristic aroma of grassy, dry leaf, scorched rice, spicy, choco, nutty, toasty, creamy, floral and palm sugar with the characteristic taste of grassy, herby, nutty, schorced rice, dry leaf, tea like, toasty, palm sugar, corn like, soy bean, watery, tarty and light acidity. Another sample (FW) had the characteristic aroma of herby, cedar, spicy, roast peanut, sweet potato, grassy, vegetabely, mint, palm sugar and slaged like dry with the characteristic taste of herby, spicy, nutty, choco, cedar, strawy, vegetable, fruity, mint, palm sugar, dry aged wood like, like green tea and light acidity. Coffee treated with F-0.55 had more various aroma and taste compared with other samples. However, all samples produced cupping score that could be categorized as a specialty coffee because the total value produced $>80$ (SCAA, 2013). 
Coffee fermentation using fructose produced a higher total score than the coffee fermentation using glucose and sucrose. Fructose and glucose are sugars categorized as reducing sugars, while sucrose is classified as a non-reducing sugar. Fructose during the roasting process will act as precursors of flavor (Avvallone et al., 2001; Jackels et al., 2006; Lin, 2010). The fructose will improve aroma and taste such as fruity and floral during the coffee processing (Lee et al., 2016). Therefore, it is understandable if the $0.55 \%$ fructose treatment provides a complete flavor response. Glucose is involved in the formation of acid and desired aldehyde compounds in the coffee brew. Fructose and glucose as reducing sugar produce more complex flavor such as acid, sweety, mint, alcohol (fruity, floral, honey, rose), esters (fruity, grape, mint, creamy, floral), furan (fruity, caramel, spicy, almond), phenol (rubbery, spicy, sweet, woody), piroles (nutty, coffee) and pyrazine (cocoa, coffee, roast, nutty, caramel) in the coffee (Lee et al., 2016).

\section{Organic Acids}

The profile of organic acids could be seen in the table 2 .
The lactic acid is the highest organic acid in all samples (green and roasted beans). The content of lactic acids is dominant in the sample $(\mathrm{F}-0.55)$ and $(\mathrm{H})$ with a range of $71.37 \pm 0.06 \%(\mathrm{db})$ to $84.32 \pm 0.13 \%(\mathrm{db})$. High levels of lactic acid caused by lactic acid bacteria are naturally found in the coffee fermentation (Avallone et al., 2001; Evangelista et al., 2015). Lactic acid bacteria are found in wet processing and semi-dry, but less common in dry processing. It is caused by plastic containers used for fermentation, low oxygen content making it suitable for the growth and metabolism of lactic acid bacteria (Bressani et al., 2018; Silva, 2014). Lactic acid bacteria may play a role in increasing the acidity in coffee. Lactic acid bacteria such as Lactobacillus plantarum can convert energy sources into lactic acids through pyruvic acid cycle to produce pyruvate. In addition, pyruvate can produce many metabolites such as acetate, ethanol, diacetyl, and acetaldehyde. These chemical compounds may play a role in increasing the acidity of the coffee.

Table 2. Organic Acid Compound of Coffee Fermentation using Different Types of Sugar compared to Honey and Fullwash

\begin{tabular}{ccccccc}
\hline & \multicolumn{5}{c}{ Treatment } \\
\cline { 2 - 7 } Organic Acid & \multicolumn{2}{c}{ Fructose $0.55 \%(\mathrm{~F}-0.55)$} & \multicolumn{2}{c}{ Honey $(\mathrm{H})$} & \multicolumn{2}{c}{ Fullwash (FW) } \\
\cline { 2 - 7 } & $\begin{array}{c}\text { Green Bean } \\
(\% \mathrm{db})\end{array}$ & $\begin{array}{c}\text { Roast Bean } \\
(\% \mathrm{db})\end{array}$ & $\begin{array}{c}\text { Green Bean } \\
(\% \mathrm{db})\end{array}$ & $\begin{array}{c}\text { Roast Bean } \\
(\% \mathrm{db})\end{array}$ & $\begin{array}{c}\text { Green Bean } \\
(\% \mathrm{db})\end{array}$ & $\begin{array}{c}\text { Roast Bean } \\
(\% \mathrm{db})\end{array}$ \\
\hline Sucsinate & $1.86 \pm 0.03^{\mathrm{aA}}$ & $1.83 \pm 0.06^{\mathrm{bB}}$ & $0.58 \pm 0.04^{\mathrm{aA}}$ & $1.53 \pm 0.04^{\mathrm{aB}}$ & $1.25 \pm 0.06^{\mathrm{Ba}}$ & $2.05 \pm 0.07^{\mathrm{cB}}$ \\
Lactic & $74.21 \pm 0.03^{\mathrm{b}}$ & $71.86 \pm 0.13^{\mathrm{c}}$ & $84.32 \pm 0.13^{\mathrm{c}}$ & $71.37 \pm 0.06^{\mathrm{b}}$ & $65.32 \pm 0.03^{\mathrm{a}}$ & $60.49 \pm 0.15^{\mathrm{a}}$ \\
Asetic & $0.52 \pm 0.03^{\mathrm{c}}$ & $8.31 \pm 0.06^{\mathrm{b}}$ & $0.34 \pm 0.05^{\mathrm{b}}$ & $6.74 \pm 0.21^{\mathrm{a}}$ & $0.18 \pm 0.03^{\mathrm{a}}$ & $6.18 \pm 0.49^{\mathrm{a}}$ \\
Sitric & $6.51 \pm 0.06^{\mathrm{b}}$ & $2.27 \pm 0.09^{\mathrm{a}}$ & $11.03 \pm 0.04^{\mathrm{c}}$ & $3.08 \pm 0.03^{\mathrm{b}}$ & $4.63 \pm 0.09^{\mathrm{a}}$ & $2.41 \pm 0.19^{\mathrm{a}}$ \\
Malic & $1.75 \pm 0.01^{\mathrm{b}}$ & $20.22 \pm 0.05^{\mathrm{c}}$ & $2.01 \pm 0.01^{\mathrm{c}}$ & $14.50 \pm 0.26^{\mathrm{a}}$ & $1.52 \pm 0.05^{\mathrm{a}}$ & $17.81 \pm 0.16^{\mathrm{b}}$ \\
Propionate & $0.91 \pm 0.11^{\mathrm{b}}$ & $1.44 \pm 0.01^{\mathrm{b}}$ & $0.03 \pm 0.01^{\mathrm{a}}$ & $1.25 \pm 0.06^{\mathrm{a}}$ & $3.10 \pm 0.14^{\mathrm{c}}$ & $1.12 \pm 0.04^{\mathrm{a}}$ \\
Butyrate & nd & nd & nd & nd & nd & nd \\
\hline
\end{tabular}

Note: Each value is expressed as an average in $\mathrm{SD}(\mathrm{n}=3)$. Numbers followed by the same letter in the same line show no significant difference based on the Duncan test $(\mathrm{p}<0.05)$. (nd= not detected)

Malic acid, succinate and citrate are organic acids naturally present in coffee beans and increases during the fermentation process (Bressani et al., 2018). Based on Table 2, the highest content of malic acid contained in the sample (F-0.55). Malic acid plays a role in green apple flavor. Among all organic acids, succinate and citrate acids are dominant in the TAV (Taste Active Value) correlated to the coffee taste. Increasing acid levels impact to flavor and brewed coffee cupping score. High value organic acids of coffee beans may be generated from the addition of sugars. The organic acid is a result of the metabolic process that remodels sugars into organic acids and energy sources (Avvallone et al., 2001; Jackels et al., 2006; Lin, 2010). In addition, the presence of butyric acid and propionic acid adversely affects the quality of coffee beans (Amorim and Amorim, 1977). However, the content of propionic acid in these samples was found in small quantities while the butyric acid was not detected in these samples. Therefore, the addition of sugar during the fermentation treatment did not affect the coffee quality.

\section{Soluble Sugars}

Table 3 shows the content of soluble sugars in coffee beans. Low molecular weight carbohydrates such as sucrose, glucose, and fructose have contributed to the formation of flavor compounds after roasting (Clarke and Vitzthum, 2008). Among the three types of soluble sugars, sucrose has the highest value compared to fructose and glucose. Sucrose is the sugar in the beans, whereas glucose and fructose are abundantly present in the pulp and muchilage (Kleinwächter, 2010). Sucrose significantly has a higher concentration in the green beans compared to the roast beans. The sucrose content in the green beans is up to $9 \%$ of the total weight and reaction of sucrose during the roasting process results in a typical coffee flavor and color. (Murkovic and Karin Derler, 2006). In addition, the soluble sugar has a potential as taste-active components contributed to the sweet taste (Rahmadian et al., 2019).

The decreasing concentration of sugars in green beans could be caused by many factors. The decrease is due to the leaching in the washing process and the use of reduced sugars by the bacteria during fermentation (Wootton, 1974). In addition, processing such as drying and roasting also significantly affects the degradation of sugars (Kleinwächter, 2010). In the fermentation process, glucose and fructose as reduced sugars will be reformed into organic acids and ethanol and energy sources. While sucrose is degraded into volatile compounds such as furan, purine, and pyridine, which give the aroma of caramel 
through a degradation process of the Maillard reaction during the process of roasting.

Glucose is one type of soluble sugars that only is found out in the roasted bean (Table 3). Glucose gives a sweet taste in the significantly impact the sweet taste of brew coffee in this research due to the low concentration. Soluble sugars with a lower molecular weight, such as fructose and glucose, were degraded early compared to sucrose. If the lower molecular weight sugars are not available anymore, sucrose will be degraded into glucose and fructose, continuing for the Maillard reaction process producing alkylpirazine compounds and other volatile compounds.

Table 3. Soluble Sugar and Secondary Metabolite Compound of Coffee Fermentation using Different Types of Sugar compared to Honey and Fullwash

\begin{tabular}{|c|c|c|c|c|c|c|}
\hline \multirow{3}{*}{ Soluble Sugar } & \multicolumn{6}{|c|}{ Treatment } \\
\hline & \multicolumn{2}{|c|}{ Fructose $0.55 \%(\mathrm{~F}-0.55)$} & \multicolumn{2}{|c|}{ Honey $(\mathrm{H})$} & \multicolumn{2}{|c|}{ Fullwash (FW) } \\
\hline & $\begin{array}{l}\text { Green Bean } \\
(\% \mathrm{db})\end{array}$ & $\begin{array}{c}\text { Roast Bean } \\
(\% \mathrm{db})\end{array}$ & $\begin{array}{l}\text { Green Bean } \\
\text { (\%db) }\end{array}$ & $\begin{array}{c}\text { Roast Bean } \\
(\% \mathrm{db})\end{array}$ & $\begin{array}{c}\text { Green Bean } \\
(\% \mathrm{db})\end{array}$ & $\begin{array}{c}\text { Roast Bean } \\
(\% \mathrm{db})\end{array}$ \\
\hline Fructose & $0.10 \pm 0.03^{a}$ & nd & $0.37 \pm 0.06^{\mathrm{b}}$ & nd & $0.17 \pm 0.01^{\mathrm{a}}$ & nd \\
\hline Glucose & $4.45 \pm 0.03^{\mathrm{a}}$ & $0.47 \pm 0.04^{b}$ & $4.92 \pm 0.07^{b}$ & $0.11 \pm 0.02^{\mathrm{a}}$ & $5.50 \pm 0.04^{\mathrm{c}}$ & $1.80 \pm 0.04^{\mathrm{c}}$ \\
\hline Sucrose & $9.67 \pm 0.05^{\mathrm{a}}$ & nd & $13.15 \pm 0.23^{b}$ & nd & $11.37 \pm 0.03^{c}$ & nd \\
\hline Caffeine & $2.59 \pm 0.04^{\mathrm{ab}}$ & $2.12 \pm 0.04^{\mathrm{a}}$ & $2.63 \pm 0.04^{b}$ & $2.05 \pm 0.04^{\mathrm{ab}}$ & $2.37 \pm 0.20^{\mathrm{a}}$ & $2.03 \pm 0.04^{\mathrm{a}}$ \\
\hline Chlorogenic Acid & $13.21 \pm 0.04^{b}$ & $10.51 \pm 0.04^{\mathrm{a}}$ & $13.39 \pm 0.04^{\mathrm{c}}$ & $10.89 \pm 0.03^{c}$ & $12.70 \pm 0.04^{\mathrm{a}}$ & $10.60 \pm 0.04^{b}$ \\
\hline
\end{tabular}

Note: Each value is expressed as an average in SD $(n=2)$. Numbers followed by the same letters in the same line show no significant difference based on Duncan's test $(\mathrm{p}<0.05)$. (nd $=$ not detected).

\section{Caffeine and Chlorogenic Acid}

The caffeine content in green beans showed differences among treatments. Table 3 shows that the (FW) caffeine content was lower than $(\mathrm{H})$ and $(\mathrm{F}-0.55)$. Caffeine content in samples $(\mathrm{F}-0.55),(\mathrm{H})$ and $(\mathrm{FW})$ in green beans were respectively $2.59 \pm 0.04 \mathrm{mg} / \mathrm{g}, 2.63 \pm 0.04 \mathrm{mg} / \mathrm{g}$ and 2.37 $\pm 0.20 \mathrm{mg} / \mathrm{g}$. Decreasing caffeine levels in the green bean were due to its natural characteristic soluble in water and organic solvents (Perrone et al., 2008). Therefore, the caffeine content in (FW) sample was decreased. The caffeine content in roasted beans was relatively stable in all types of treatments. TAV value of $(\mathrm{F}-0.55),(\mathrm{H})$ and $(\mathrm{FW})$ were respectively $2.65 \mathrm{mg} / \mathrm{g}, 2.56 \mathrm{mg} / \mathrm{g}$ and $2.54 \mathrm{mg} / \mathrm{g}$. It is supposed that caffeine has a relatively stable properties against degradation and in a variety of drying conditions (Dong et al., 2017).

Caffeine is a chemical compound classified as phenolics contributing to the formation of a bitter taste in coffee (Perrone et al., 2008). A high concentration of caffeine in this study has a significant impact on the bitter taste in brew coffee. Caffeine is a derivative xantine known as central nervous system stimulant and is generally associated with improvements in alertness, learning capacity and performance. The characteristic of bitter taste from caffeine is an important determination for the formation of flavor (Farah et al., 2006).

The content of chlorogenic acid in all coffee samples was demonstrated in Table 3. The content of chlorogenic acid in green bean samples $(\mathrm{F}-0.55),(\mathrm{H})$ and $(\mathrm{FW})$ were respectively $13.21 \pm 0.04 \mathrm{mg} / \mathrm{g}, 13.39 \pm 0.04 \mathrm{mg} / \mathrm{g}$ and $12.70 \pm 0.04 \mathrm{mg} / \mathrm{g}$. The chlorogenic acid content in green beans $(\mathrm{H})$ has a higher value than the green bean samples of (F-0.55) and (FW). This is because of the absence of a washing process in the sample $(\mathrm{H})$. It has been reported the decreased level of chlorogenic acid in the green beans is caused by easily soluble in water and organic solvents (Perrone et al., 2008). Generally, chlorogenic acid content in the green bean samples was higher than the sample roasted bean (Table 3). Decreased levels of chlorogenic acid in the sample roasted beans because of the thermal instability and further processing, especially the roasting process of coffee beans. Chlorogenic acid also has a bitter taste and translucent colour. It has been reported that the increase in the temperature roasting increasingly degrades the chlorogenic acid (Clifford, 1972) up to 93\% off for the level of dark (Farah et al., 2006).

The content of chlorogenic acids in (F-0.55), (H) and (FW) were respectively $10.51 \mathrm{mg} / \mathrm{g}, 10.89 \mathrm{mg} / \mathrm{g}$ and $10.60 \mathrm{mg} / \mathrm{g}$ which was relatively stable on the all roasted samples. Chlorogenic acid and chlorogenic acid lactones quinat could be formed during the roasting process of coffee (Farah et al., 2005), which contributed to an increase in the bitterness of coffee beverage (Ginz and Engelhardt, 2001). Additionally it has been reported that chlorogenic acid in coffee drinks became one of the highest sources compared to other beverages (Clifford, 2000). Arabica coffee drink cup (200 ml) contains 70-200 mg chlorogenic acid (Clifford, 1999). It is also reported that the chlorogenic acid as sources of natural antioxidants (Chen et al., 2019). Therefore, these coffee beans in this research could be developed as a functional drink with beneficial effect in the body.

\section{Amino Acids}

The content of amino acids in all samples were shown in Table 4. The heat generated by the coffee beans during roasting for a long time can degrade amino acids in coffee beans (Clark, 1987). Glutamate is the highest amino acid in the green beans and roasted beans which were relatively (F-0.55) $1.87 \pm 0.01 \mathrm{mg} / \mathrm{g},(\mathrm{H}) 2.14 \pm 0.04 \mathrm{mg} / \mathrm{g}$ and $(\mathrm{FW})$ $2.02 \pm 0.01 \mathrm{mg} / \mathrm{g}$ while in the roasted beans (F-0.55) 1.34 $\pm 0.01 \mathrm{mg} / \mathrm{g}$, (H) $1.66 \pm 0.05 \mathrm{mg} / \mathrm{g}$ and $(\mathrm{FW}) 1.96 \pm 0.05$ $\mathrm{mg} / \mathrm{g}$. TAV value in green beans of sample $(\mathrm{F}-0.55),(\mathrm{H})$ and (FW) were respectively $6.23 \mathrm{mg} / \mathrm{g}, 7.13 \mathrm{mg} / \mathrm{g}$ and 6.73 $\mathrm{mg} / \mathrm{g}$ while in the roasted bean of sample $(\mathrm{F}-0.55),(\mathrm{H})$ and (FW) were respectively $4.47 \mathrm{mg} / \mathrm{g}, 5.53 \mathrm{mg} / \mathrm{g}$ and 6.53 $\mathrm{mg} / \mathrm{g}$. Glutamate is an amino acid classified as the umami 
taste, but in this study, the high glutamate concentrations did not significantly impact the umami taste in coffee infusion. They only have a small amount of concentration in the total amino acids contained by the coffee beans. In addition, the glutamate and asparagine have been deaminated into glutamic acid and aspartic acid for acid hydrolysis process (Chen et al., 2007).

Table 4. Amino Acid Composition in Fermented Coffee Using 0.55\% Fructose

\begin{tabular}{|c|c|c|c|c|c|c|c|c|}
\hline \multirow{3}{*}{$\begin{array}{c}\text { Amino } \\
\text { Acid }\end{array}$} & \multirow{3}{*}{$\begin{array}{c}\mathrm{MW}^{x} \\
\left(\mathrm{~g} \mathrm{~mol}^{-1}\right)\end{array}$} & \multicolumn{6}{|c|}{ Treatment } & \multirow{3}{*}{$\begin{array}{c}\text { Taste } \\
\text { Description }\end{array}$} \\
\hline & & \multicolumn{2}{|c|}{ Fructose $0,55 \%$ (A1) } & \multicolumn{2}{|c|}{ Honey $(\mathrm{A} 10)$} & \multicolumn{2}{|c|}{ Full wash (A11) } & \\
\hline & & $\begin{array}{c}\text { Green Bean } \\
(\% \mathrm{db})\end{array}$ & $\begin{array}{c}\text { Roasted Bean } \\
(\% \mathrm{db})\end{array}$ & $\begin{array}{c}\text { Green Bean } \\
(\% \mathrm{db})\end{array}$ & $\begin{array}{c}\text { Roast Bean } \\
(\% \mathrm{db})\end{array}$ & $\begin{array}{c}\text { Green Bean } \\
(\% \mathrm{db})\end{array}$ & $\begin{array}{c}\text { Roast Bean } \\
(\% \mathrm{db})\end{array}$ & \\
\hline $\mathrm{Asp}^{C}$ & 133.11 & $0.72 \pm 0.02^{\mathrm{a}}$ & $0.62 \pm 0.03^{\mathrm{a}}$ & $0.84 \pm 0.03^{b}$ & $0.77 \pm 0.02^{\mathrm{b}}$ & $0.92 \pm 0.03^{\mathrm{c}}$ & $0.73 \pm 0.03^{\mathrm{ab}}$ & 1,3 \\
\hline $\mathrm{Thr}^{B}$ & 119.12 & $0.26 \pm 0.02^{\mathrm{a}}$ & $0.22 \pm 0.05^{\mathrm{a}}$ & $0.32 \pm 0.03^{b}$ & $0.26 \pm 0.02^{\mathrm{a}}$ & $0.35 \pm 0.02^{\mathrm{b}}$ & $0.25 \pm 0.03^{a}$ & 3,4 \\
\hline $\operatorname{Ser}^{B}$ & 105.09 & $0.33 \pm 0.05^{\mathrm{a}}$ & $0.18 \pm 0.01^{\mathrm{a}}$ & $0.41 \pm 0.01^{\mathrm{b}}$ & $0.21 \pm 0.04^{\mathrm{a}}$ & $0.45 \pm 0.01^{\mathrm{b}}$ & $0.22 \pm 0.04^{\mathrm{a}}$ & 2,3 \\
\hline $\mathrm{Glu}^{C}$ & 147.13 & $1.87 \pm 0.01^{\mathrm{a}}$ & $1.34 \pm 0.01^{\mathrm{a}}$ & $2.14 \pm 0.04^{\mathrm{c}}$ & $1.66 \pm 0.05^{\mathrm{b}}$ & $2.02 \pm 0.01^{\mathrm{b}}$ & $1.96 \pm 0.05^{\mathrm{c}}$ & 5 \\
\hline Pro & 115.13 & $0.41 \pm 0.06^{\mathrm{a}}$ & $0.33 \pm 0.06^{\mathrm{a}}$ & $0.49 \pm 0.05^{\mathrm{a}}$ & $0.43 \pm 0.02^{b}$ & $0.51 \pm 0.06^{\mathrm{a}}$ & $0.46 \pm 0.01^{\mathrm{b}}$ & $6,3,7,8,9$ \\
\hline Gly $^{A}$ & 75.07 & $0.56 \pm 0.01^{\mathrm{a}}$ & $0.40 \pm 0.03^{\mathrm{a}}$ & $0.63 \pm 0.02^{\mathrm{a}}$ & $0.54 \pm 0.04^{b}$ & $0.62 \pm 0.08^{\mathrm{a}}$ & $0.56 \pm 0.01^{\mathrm{b}}$ & 10,3 \\
\hline $\mathrm{Ala}^{A}$ & 89.09 & $0.44 \pm 0.05^{\mathrm{a}}$ & $0.29 \pm 0.02^{\mathrm{a}}$ & $0.49 \pm 0.05^{\mathrm{a}}$ & $0.38 \pm 0.05^{b}$ & $0.45 \pm 0.08^{\mathrm{a}}$ & $0.44 \pm 0.01^{b}$ & $1,3,6$ \\
\hline $\mathrm{Cys}^{F}$ & 240.30 & $0.09 \pm 0.01^{\mathrm{a}}$ & $0.01 \pm 0.01^{\mathrm{a}}$ & $0.29 \pm 0.05^{\mathrm{b}}$ & $0.05 \pm 0.02^{\mathrm{a}}$ & $0.32 \pm 0.02^{\mathrm{b}}$ & $0.04 \pm 0.03^{\mathrm{a}}$ & 12 \\
\hline $\mathrm{Val}^{A}$ & 117.15 & $0.48 \pm 0.02^{\mathrm{a}}$ & $0.46 \pm 0.01^{\mathrm{ab}}$ & $0.54 \pm 0.03^{b}$ & $0.43 \pm 0.02^{\mathrm{a}}$ & $0.50 \pm 0.01^{\mathrm{ab}}$ & $0.48 \pm 0.02^{\mathrm{b}}$ & 10,9 \\
\hline $\operatorname{Met}^{F}$ & 149.20 & $0.11 \pm 0.03^{\mathrm{a}}$ & $0.08 \pm 0.04^{\mathrm{a}}$ & $0.06 \pm 0.05^{\mathrm{a}}$ & $0.04 \pm 0.04^{\mathrm{a}}$ & $0.11 \pm 0.06^{\mathrm{a}}$ & $0.10 \pm 0.03^{\mathrm{a}}$ & 13,15 \\
\hline $\mathrm{Ile}^{A}$ & 131.18 & $0.33 \pm 0.06^{\mathrm{a}}$ & $0.26 \pm 0.02^{\mathrm{a}}$ & $0.39 \pm 0.02^{\mathrm{a}}$ & $0.32 \pm 0.04^{\mathrm{ab}}$ & $0.37 \pm 0.02^{\mathrm{a}}$ & $0.34 \pm 0.03^{b}$ & 14,10 \\
\hline $\mathrm{Leu}^{A}$ & 131.18 & $0.77 \pm 0.02^{\mathrm{a}}$ & $0.53 \pm 0.03^{\mathrm{a}}$ & $0.90 \pm 0.04^{c}$ & $0.70 \pm 0.02^{b}$ & $0.83 \pm 0.04^{b}$ & $0.82 \pm 0.03^{c}$ & 14,10 \\
\hline $\operatorname{Tyr}^{G}$ & 181.19 & $0.19 \pm 0.06^{\mathrm{a}}$ & $0.13 \pm 0.02^{\mathrm{a}}$ & $0.27 \pm 0.02^{\mathrm{a}}$ & $0.24 \pm 0.02^{\mathrm{b}}$ & $0.27 \pm 0.05^{\mathrm{a}}$ & $0.24 \pm 0.03^{b}$ & 16,19 \\
\hline $\mathrm{Phe}^{G}$ & 165.19 & $0.34 \pm 0.01^{\mathrm{a}}$ & $0.32 \pm 0.03^{\mathrm{a}}$ & $0.46 \pm 0.02^{b}$ & $0.37 \pm 0.03^{\mathrm{a}}$ & $0.44 \pm 0.01^{b}$ & $0.43 \pm 0.03^{b}$ & $18,17,9$ \\
\hline $\mathrm{His}^{E}$ & 155.18 & $0.43 \pm 0.05^{\mathrm{a}}$ & $0.32 \pm 0.04^{\mathrm{a}}$ & $0.43 \pm 0.04^{\mathrm{a}}$ & $0.35 \pm 0.02^{\mathrm{ab}}$ & $0.42 \pm 0.05^{\mathrm{a}}$ & $0.40 \pm 0.02^{\mathrm{b}}$ & 20,5 \\
\hline $\operatorname{Lys}^{E}$ & 146.19 & $0.50 \pm 0.04^{\mathrm{a}}$ & $0.10 \pm 0.03^{\mathrm{a}}$ & $0.65 \pm 0.06^{b}$ & $0.21 \pm 0.04^{b}$ & $0.74 \pm 0.03^{c}$ & $0.21 \pm 0.07^{\mathrm{b}}$ & $3,10,9$ \\
\hline $\operatorname{Arg}^{E}$ & 174.20 & $0.81 \pm 0.04^{\mathrm{a}}$ & $n d$ & $0.95 \pm 0.06^{\mathrm{b}}$ & $0.51 \pm 0.03^{b}$ & $1.58 \pm 0.05^{\mathrm{c}}$ & $0.55 \pm 0.03^{b}$ & 9 \\
\hline Try $^{G}$ & 204.23 & $0.16 \pm 0.02^{\mathrm{a}}$ & $0.04 \pm 0.01^{\mathrm{a}}$ & $0.11 \pm 0.03^{\mathrm{a}}$ & $0.08 \pm 0.03^{\mathrm{a}}$ & $0.11 \pm 0.07^{\mathrm{a}}$ & $0.19 \pm 0.04^{\mathrm{b}}$ & 3,10 \\
\hline
\end{tabular}

Note: (x): Wong. KH et al (2008), (A): simple aliphatic, (B): hydroxy-aliphatic, (C): dicarboxylic (acid), (D): amide, (E): basic amino acids, (F): acid amino with sulfur, (G): aromatic. (1): Fruity (like fresh dates), (2): Fruity (slightly like, fresh dates), (3): Pleasant / sweet, (4): Astringent sweet taste, (5): Sour taste, (6) : Flowery, (7): Pandan, (8): Slightly persimmon, (9): Bitter taste, (10): Caramel like, (11): Fruity, (12): Sulphury, (13): Fried potatoes, (14): Burnt, (15): Cracker, (16): Flowery (slightly dried roses), (17): Almonds, (18): Flowery (dried roses), (19): Sweet taste, (20): Slight sweet. Each value is expressed as an average with SD ( $\mathrm{n}=2)$. Numbers followed by the same letters in the same line show no significant difference based on Duncan's test $(\mathrm{p}<0.05)$. (nd $=$ not detected).

Amino acids classified as the sweet perception consist of five types: glycine, alanine, serine, threonine and lysine. The sweetness threshold of the five amino acids were $25 \mathrm{mg} / \mathrm{g}, 12 \mathrm{mg} / \mathrm{g}, 25 \mathrm{mg} / \mathrm{g}, 35 \mathrm{mg} / \mathrm{g}$ and $0.5 \mathrm{mg} / \mathrm{g}$ and the lowest threshold value was for lysine. In the coffee samples, the sweet flavour was derived from sugars and amino acids. However, sugars have a bigger role in the formation of the sweet taste in coffee. In Table 5 indicated that the value of TAV sugar is higher than the amino acids in the green beans. In the roasted bean sugars much more were involved in the formation of aroma flavor through a series of Maillard and caramelization process.

Tabel 5. Taste Active Value (TAV) of Non-Volatile Compounds Green and Roast Bean Coffee

\begin{tabular}{|c|c|c|c|c|c|c|c|c|}
\hline \multirow{4}{*}{ Taste } & \multirow{4}{*}{ Components } & \multirow{4}{*}{$\begin{array}{c}\text { Threshold } \\
(m g / g)\end{array}$} & \multicolumn{6}{|c|}{ Taste Active Value (TAV) } \\
\hline & & & & & \multirow{2}{*}{\multicolumn{2}{|c|}{$\begin{array}{c}\text { Green Bean } \\
\text { Honey }(\mathbf{A 1 0}) \\
\end{array}$}} & & \\
\hline & & & \multicolumn{2}{|c|}{ Fructose $0.55 \%(\mathrm{A1})$} & & & \multicolumn{2}{|c|}{ Fullwash (A11) } \\
\hline & & & $\begin{array}{l}\text { Cons } \\
(m g / g)\end{array}$ & $\begin{array}{c}\text { DoT } \\
(m g / g)\end{array}$ & $\begin{array}{c}\text { Cons } \\
(m g / g)\end{array}$ & $\begin{array}{c}\text { DoT } \\
(m g / g)\end{array}$ & $\begin{array}{l}\text { Cons } \\
(m g / g)\end{array}$ & $\begin{array}{c}\text { DoT } \\
(m g / g)\end{array}$ \\
\hline \multirow[t]{3}{*}{ Sweet (sugar) } & Glucose & $18.00^{\mathrm{a}}$ & 4.45 & 0.25 & 4.92 & 0.27 & 5.50 & 0.31 \\
\hline & Fructose & $10.20^{\mathrm{a}}$ & 0.10 & 0.01 & 0.37 & 0.04 & 0.17 & 0.02 \\
\hline & Sucrose & - & 9.67 & - & 13.15 & - & 11.37 & - \\
\hline \multirow[t]{7}{*}{ Sour (organic acid) } & Suksinate & $22.00^{\mathrm{a}}$ & 1.86 & 0.08 & 0.58 & 0.03 & 1.25 & 0.06 \\
\hline & Laktic & $80.00^{\mathrm{a}}$ & 74.21 & 0.93 & 84.32 & 1.05 & 65.32 & 0.82 \\
\hline & Asetic & $1.99^{\mathrm{a}}$ & 0.52 & 0.26 & 0.34 & 0.17 & 0.18 & 0.09 \\
\hline & Citric & $4.3^{\mathrm{a}}$ & 6.51 & 1.51 & 11.03 & 2.57 & 4.63 & 1.08 \\
\hline & Malic & $7.3^{\mathrm{a}}$ & 1.75 & 0.24 & 2.10 & 0.29 & 1.52 & 0.21 \\
\hline & Propionate & - & 0.91 & - & 0.03 & - & 3.10 & - \\
\hline & Butyric & - & nd & nd & nd & nd & nd & nd \\
\hline \multirow[t]{2}{*}{ Umami (amino acid) } & Aspartic & $1.00^{\mathrm{b}}$ & 0.72 & 0.72 & 0.84 & 0.84 & 0.92 & 0.92 \\
\hline & Glutamic & $0.30^{\mathrm{b}}$ & 1.87 & 6.23 & 2.14 & 7.13 & 2.02 & 6.73 \\
\hline \multirow[t]{5}{*}{ Sweet (amino acid) } & Glycine & $25.00^{\mathrm{a}}$ & 0.56 & 0.02 & 0.63 & 0.03 & 0.62 & 0.02 \\
\hline & Alanine & $12.00^{\mathrm{a}}$ & 0.44 & 0.04 & 0.49 & 0.04 & 0.45 & 0.04 \\
\hline & Serine & $25.00^{\mathrm{a}}$ & 0.33 & 0.01 & 0.41 & 0.02 & 0.45 & 0.02 \\
\hline & Threonine & $35.00^{\mathrm{a}}$ & 0.26 & 0.01 & 0.32 & 0.01 & 0.35 & 0.01 \\
\hline & Lysine & $0.50^{\mathrm{b}}$ & 0.50 & 1.00 & 0.65 & 1.30 & 0.74 & 1.48 \\
\hline \multirow[t]{9}{*}{ Bitter (amino acid) } & Tryptophan & - & 0.16 & - & 0.11 & - & 0.11 & - \\
\hline & Arginine & $0.50^{\mathrm{b}}$ & 0.81 & 1.62 & 0.95 & 1.90 & 1.58 & 3.16 \\
\hline & Histidine & $0.20^{\mathrm{b}}$ & 0.43 & 2.15 & 0.43 & 2.15 & 0.42 & 2.10 \\
\hline & Tyrosine & - & 0.19 & - & 0.27 & - & 0.27 & - \\
\hline & Methionine & $5.00^{\mathrm{a}}$ & 0.11 & 0.02 & 0.06 & 0.01 & 0.11 & 0.02 \\
\hline & Valine & $0.40^{\mathrm{b}}$ & 0.48 & 1.20 & 0.54 & 1.35 & 0.50 & 1.25 \\
\hline & Phenylalanine & $0.90^{\mathrm{b}}$ & 0.34 & 0.38 & 0.46 & 0.51 & 0.44 & 0.49 \\
\hline & Isoleucine & $0.90^{\mathrm{b}}$ & 0.33 & 0.37 & 0.39 & 0.43 & 0.37 & 0.41 \\
\hline & Leucine & $1.90^{\mathrm{b}}$ & 0.77 & 0.41 & 0.90 & 0.47 & 0.83 & 0.44 \\
\hline Sour (amino acid) & Aspargine & - & - & - & - & - & - & - \\
\hline \multirow[t]{2}{*}{ Bitter (phenolic) } & Caffeine & $0.80^{\mathrm{a}}$ & 2.59 & 3.24 & 2.63 & 3.29 & 2.37 & 2.96 \\
\hline & Chlorogenic & - & 13.21 & - & 13.39 & - & 12.70 & - \\
\hline
\end{tabular}




\section{Continue}

\begin{tabular}{|c|c|c|c|c|c|c|c|c|}
\hline \multirow{4}{*}{ Taste } & \multirow{4}{*}{ Components } & \multirow{4}{*}{$\begin{array}{c}\text { Threshold } \\
(m g / g)\end{array}$} & \multicolumn{6}{|c|}{ Taste Active Value (TAV) } \\
\hline & & & & & \multirow{2}{*}{\multicolumn{2}{|c|}{$\begin{array}{c}\text { Roasted Bean } \\
\text { Honey (A10) }\end{array}$}} & & \\
\hline & & & \multicolumn{2}{|c|}{ Fructose $0.55 \%$ (A1) } & & & \multicolumn{2}{|c|}{ Fullwash (A11) } \\
\hline & & & $\begin{array}{l}\text { Cons } \\
(m g / g)\end{array}$ & $\begin{array}{c}\text { DoT } \\
(m g / g)\end{array}$ & $\begin{array}{c}\text { Cons } \\
(m g / g)\end{array}$ & $\begin{array}{l}\text { DoT } \\
(m g / g)\end{array}$ & $\begin{array}{l}\text { Cons } \\
(m g / g)\end{array}$ & $\begin{array}{c}\text { DoT } \\
(\mathrm{mg} / \mathrm{g})\end{array}$ \\
\hline \multirow[t]{3}{*}{ Sweet (sugar) } & Glucose & $18.00^{\mathrm{a}}$ & 0.47 & 0.03 & 0.11 & 0.01 & 1.80 & 1.10 \\
\hline & Fructose & $10.20^{\mathrm{a}}$ & nd & nd & nd & nd & nd & nd \\
\hline & Sucrose & - & - & - & - & - & - & - \\
\hline \multirow{7}{*}{ Sour (organic acid) } & Suksinate & $22.00^{\mathrm{a}}$ & 1.83 & 0.08 & 1.53 & 0.07 & 2.05 & 0.09 \\
\hline & Laktic & $80.00^{\mathrm{a}}$ & 71.86 & 0.90 & 71.37 & 0.89 & 60.49 & 0.76 \\
\hline & Asetic & $1.99^{\mathrm{a}}$ & 8.31 & 4.18 & 6.74 & 3.39 & 6.18 & 3.11 \\
\hline & Citric & $4.30^{\mathrm{a}}$ & 2.27 & 0.53 & 3.08 & 0.72 & 2.41 & 0.56 \\
\hline & Malic & $7.30^{\mathrm{a}}$ & 20.22 & 2.77 & 14.50 & 1.99 & 17.81 & 2.44 \\
\hline & Propionate & - & 1.44 & - & 1.25 & - & 1.12 & - \\
\hline & Butyric & - & nd & nd & nd & nd & nd & nd \\
\hline \multirow[t]{2}{*}{ Umami (amino acid) } & Aspartic & $1.00^{\mathrm{b}}$ & 0.62 & 0.62 & 0.77 & 0.77 & 0.73 & 0.73 \\
\hline & Glutamic & $0.30^{\mathrm{b}}$ & 1.34 & 4.47 & 1.66 & 5.53 & 1.96 & 6.53 \\
\hline \multirow[t]{5}{*}{ Sweet (amino acid) } & Glycine & $25.00^{\mathrm{a}}$ & 0.40 & 0.02 & 0.54 & 0.02 & 0.56 & 0.02 \\
\hline & Alanine & $12.00^{\mathrm{a}}$ & 0.29 & 0.02 & 0.38 & 0.03 & 0.44 & 0.04 \\
\hline & Serine & $25.00^{\mathrm{a}}$ & 0.18 & 0.01 & 0.21 & 0.01 & 0.22 & 0.01 \\
\hline & Threonine & $35.00^{\mathrm{a}}$ & 0.22 & 0.01 & 0.26 & 0.01 & 0.25 & 0.01 \\
\hline & Lysine & $0.50^{\mathrm{b}}$ & 0.10 & 0.20 & 0.21 & 0.42 & 0.21 & 0.42 \\
\hline \multirow[t]{9}{*}{ Bitter (amino acid) } & Tryptophan & - & 0.04 & - & 0.08 & - & 0.19 & - \\
\hline & Arginine & $0.50^{\mathrm{b}}$ & nd & nd & 0.51 & 1.02 & 0.55 & 1.10 \\
\hline & Histidine & $0.20^{\mathrm{b}}$ & 0.32 & 1.60 & 0.21 & 1.05 & 0.21 & 1.05 \\
\hline & Tyrosine & - & 0.13 & - & 0.24 & - & 0.24 & - \\
\hline & Methionine & $5.00^{\mathrm{a}}$ & 0.08 & 0.02 & 0.04 & 0.01 & 0.10 & 0.02 \\
\hline & Valine & $0.40^{\mathrm{b}}$ & 0.46 & 1.15 & 0.43 & 1.08 & 0.48 & 1.20 \\
\hline & Phenylalanine & $0.90^{\mathrm{b}}$ & 0.32 & 0.36 & 0.37 & 0.41 & 0.43 & 0.48 \\
\hline & Isoleucine & $0.90^{\mathrm{b}}$ & 0.26 & 0.29 & 0.32 & 0.36 & 0.34 & 0.38 \\
\hline & Leucine & $1.90^{\mathrm{b}}$ & 0.53 & 0.28 & 0.7 & 0.37 & 0.82 & 0.43 \\
\hline & Aspargine & - & 0.62 & - & 0.77 & - & 0.73 & - \\
\hline \multirow[t]{2}{*}{ Bitter (phenolic) } & Caffeine & $0.80^{\mathrm{a}}$ & 2.12 & 2.65 & 2.05 & 2.56 & 2.03 & 2.54 \\
\hline & Chlorogenic & - & 10.51 & - & 10.89 & - & 10.60 & - \\
\hline
\end{tabular}

Note: GB: Green Bean; RB: Roasted Bean; (a): Hufnagel and Hofmann, 2008; (b): Chen and Zhang (2007)

Nine amino acids were classified as having a bitter taste consisting of arginine, histidine, methionine, valine, phenylalanine, isoleucine, leucine, tyrosine and tryptophan with a taste threshold value of respectively $0.50 \mathrm{mg}$ g, 0.20 $\mathrm{mg} / \mathrm{g}, 5.00 \mathrm{mg} / \mathrm{g}, 0.40 \mathrm{mg} / \mathrm{g}, 0.90 \mathrm{mg} / \mathrm{g}, 0.90 \mathrm{mg} / \mathrm{g}$ and $1.90 \mathrm{mg} / \mathrm{g}$ but tyrosine and tryptophan were undiscovered in the literature. Three of them are aromatic amino acids consisting of phenylalanine, tyrosine and tryptophan (Wong et al., 2008).

According to Wong et al. (2008), temperature, substrate ratio, $\mathrm{pH}$, and time can affect flavor notes formed during the Maillard reaction. Some amino acids, such as aspartic acid and glutamic acid have naturally low $\mathrm{pH}$ values (respectively $\mathrm{pH} 3.0$ and 3.2), while others are in the $\mathrm{pH}$ range of 5.3 to 5.8. Various detectable aroma of arginine, aspartic acid and cysteine in $\mathrm{pH} 5.2$ implies conformity to the formation of flavor. Serine, proline, and phenylalanine provide significant fruity taste and floral aroma. Alanine produces the smell of flowers and also aspartic acid produces a pleasant smell (pleasant odor). The aroma is detected from isoleucine, leucine, lysine and threonine like caramel and become more distinct in a longer heating. No odor was detected from arginine, glutamic acid and histidine, even after a change of color. Detection of odor depends on the concentration and threshold of major odor impact compounds as well as the sensitivity of the human nose. In addition, it was reported that Maillard reaction between amino acids and reducing sugars produced smells like popcorn roast (Hunter et al., 1969). In this point of view, Maillard reaction may affect the coffee flavor during the processing. Generally, all of the amino acid contents were similar in all samples.

\section{CONCLUSION}

Based on these results, fructose is a type of sugar suitable as a fermentation substrate used in the coffee processing by $0.55 \%$. Fermentation using $0.55 \%$ fructose gave positive effect on the profile of nonvolatile compounds such as organic acids, amino acids, caffeine, and chlorogenic acid content of which is correlated to the increase steeping coffee cupping score until it reaches a value $>84(85.25)$, where it is classified as an excellence coffee. The content of caffeine and chlorogenic acid was relatively stable in all samples and contributed to the coffee flavour. The chlorogenic acid also has the potential as an antioxidant. Therefore the coffee processing with sugar addition may affect the coffee flavour in general for the brewed taste and beneficial effects in body. Furthermore, to understand the effect of sugar addition to the flavor coffee, study of key aroma should be conducted and to understand the beneficial effects of the coffee beans, the study of antioxidant activities should be examined.

\section{ACKNOWLEDGEMENT}

The authors thank to Department of Food Science and Technology, Faculty of Agricultural Technology Universitas Gadjah Mada, Yogyakarta, Indonesia and Liberico Coffee Roastery Madiun Indonesia.

\section{REFERENCES}

Amorim, H.V and Amorim, V.L. 1977. Coffee enzymes and coffee quality. In: Enzymes in Food and Beverage Processing, pp. 259274.

Anonymous. 2005. AOAC (Association of Official Analytical Chemists). Official Methods of Analysis of the Association of Official Analytical Chemist. Chemist Inc. New York.

Avallone, S., Guyot, B., Brillouet, JM, Olguin, E., and Guiraud, J.P. 
2001. Microbiological and biochemical study of coffee fermentation. Current Microbiology. 42(4):252-256.

Baggenstoss, J., Poisson, L., Kaegi, R., Perren, R., and Escher, F. 2008. Coffee roasting and aroma formation: Application of different timetemperature conditions. Journal of Agricultural and Food Chemistry. 56(14):5836-5846.

Bressani, A.P.P., Martinez, S.J., Evangelista, S.R., Dias, D.R. and Schwan, R.F., 2018. Characteristics of fermented coffee inoculated with yeast starter cultures using different inoculation methods. LWT- Food Science and Technology. 92:212-219.

Bytof, G., Peter, S.K. 2005. Influence of processing on the generation of $g$ -aminobutyric acid in green coffee beans. 245-250.

Chen, D.W. and Zhang, M. 2007. Non-volatile taste-active compounds in the meat of Chinese mitten crab (Eriocheir sinensis). Food Chemsitry. 104(3):1200-1205.

Chen, X., Kitts, D.D., Ji, D. and Ding, J. 2019. Free radical scavenging activities of phytochemical mixtures and aqueous methanolic extracts recovered from processed coffee leaves. International Journal of Food Science \& Technology. 54(10):2872-2879. https://doi.org/10.1111/ ijfs.14099.

Clarke, R.J. and Macrae, R. 1987. Coffee chemestry. Volume 1. New York, USA: Elsevier Applied Science.

Clarke, R. and Vitzthum, O.G. 2008. Coffee: Recent developments. London: John Wiley and Sons.

Clifford, M.N. 1972. The phenolic compounds of green and roasted coffee beans. Glasgow: University of Strathclyde.

Clifford, M.N. 1999. Chlorogenic acids and other cinnamates - Nature, occurrence and dietary burden. Journal of the Science of Food and Agriculture. 79(3):362-372.

Clifford, M.N. 2000. Chlorogenic acids and other cinnamates - Nature, occurrence, dietary burden, absorption and metabolism. Journal of the Science of Food and Agriculture. 80(7):1033-1043,

De Maria, C.A.B., Trugo, L.C., Moreira, R.F.A., and Petracco, M. 1995. Simultaneous determination of total chlorogenic acid, trigonelline and caffeine in green coffee samples by high performance gel filtration chromatography. Food Chemistry. 52:447-449.

Dong, W., Hu, R., Chu, Z., Zhao, J., and Tan, L. 2017. Effect of different drying techniques on bioactive components, fatty acid, compotition, and volatile profile of Robusta coffee beans. Food Chemistry. 234:121-130.

Dorfner, R., Ferge, T., Kettrup, A., Zimmermann, R., and Yeretzian, C. 2003. Real-time monitoring of 4-vinylguaiacol, guaiacol, and phenol during coffee roasting by resonant laser ionization time-of-flight mass spectrometry. Journal of Agricultural and Food Chemistry. 51(19):5768-5773.

Duarte, G.S., Pereira, A.A. and Farah, A. 2010. Chlorogenic acids and other compounds relevant in Brazilian coffees are processed by semidry and wet post-harvesting methods. Food Chemistry. 118(3):851855 .

Evangelista, S.R., Miguel, M.G.P.C., Silva, C.F., Pinheiro, A.C.M. and Schwan, R.F. 2015. Microbiological diversity associated with the spontaneous fermentation of wet method of coffee. International Journal of Food Microbiology. 210:102-112.

FAO. 2004. Fermentation of coffee control of operation. Rome, Italy: Food and Agricultural Organization.

Farah, A., de Paulis, T., Trugo, L.C. and Martin, P.R. 2005. Effect of roasting on the formation of chlorogenic acid lactones in coffee. Journal of Agricultural and Food Chemistry. 53(5):1505-1513. http:// dx.doi.org/10.1021/jf048701t.

Farah, A., de Paulis, T., Moreira, D.P., Trugo, L.C. and Martin, P.R., 2006. Chlorogenic acids and lactones in regular and water-decaffeinated arabica coffees. Journal of Agricultural and Food Chemistry. 54(2):374-381.

Ginz, M., Balzer, H.H., Bradbury, A.G.W. and Maier, H.G., 2000. Formation of aliphatic acids by carbohydrate degradation during roasting of coffee.European Food Research and Technology. 211(6):404-410. http://dx.doi.org/10.1007/s002170000215.

Hufnagel, J.C. and T. Hofmann. 2008. Quantitative Reconstruction of the Nonvolatile Sensometabolome of a Red Wine. Journal of Agricultural and Food Chemistry. 56(19):9190-9199.

Hunter, I.R., Walden, M.K., Scherer, J.R. and Lundin, R.E. 1969.
Preparation and properties of 1,4,5,6-Tetrahydro-2-acetopyridine, a cracker-odor constituent of bread aroma. Cereal Chemistry. 46:189195.

Illy, A. and Viani, R. 2005. Espresso coffee: The science of quality (2nd ed.). London, UK: Elsevier Academic Press.

Jackels, SC., Jackels, C.F., Vallejos, C., Kleven, S., Rivas, R. and FraserDauphinee, S. 2006. Control of the coffee fermentation process and quality of the resulting roasted coffee: Studies in the field of laboratory and on small farms in Nicaragua during the 2005-06 harvest. In the 21st International Scientific Colloquium on Coffee - Post-harvest processing and green coffee quality. Montpellier, France.

Kleinwächter, M. and Selmar, D. 2010. Influence of drying on the content of sugars in processed wet green Arabica coffees. Food Chemistry. 119(2):500-504.

Knopp, S., Bytof, G., and Selmar, D. 2005. Influence of processing on the content of sugars in green Arabica coffee beans. European Food Research and Technology. 223(2):195-201.

Lee, L.W, Cheong, M.W., Curran, P., Yu, B. and Liu, S.Q. 2015. Coffee fermentation and flavor - An intricate and delicate relationship. Food Chemistry. 185:182-191.

Lee, L.W., Cheong, M.W., Curran, P., Yu, B., and Liu, S.Q. 2016. Modulation of coffee aroma via the fermentation of green coffee beans with Rhizopus oligosporus: I. Green coffee. Food Chemistry. 211:916-924.

Lin, C.C. 2010. Approach of improving coffee industry in Taiwan Promote quality of coffee bean by fermentation. The Journal of International Management Studies. 5(1):154-159.

Mori, E.E.M., Bragagnolo, N., Morgano, M.A., Anjos, V.D.A., Yotsuyanagi, K., Faria, E.V. 2003. Brazilian coffee growing regions and quality of natural, pulped natural and washed coffees. Food and Food Ingredients Journal of Japan, 208 (1), 416-423.

Murkovic. M. and Derler, K. 2006. Analysis of amino acids and carbohydrates in green coffee. Journal of biochemical and biophysical methods. 69:25-32.

Perrone, D., Donangelo, C.M. and Farah, A. 2008. Fast simultaneous analysis of caffeine, trigonellin, nicotinic acid and sucrose in coffee by liquid chromatography-mass spectroscopy. Food Chemistry. 110 (4):1030-1035.

Perwita, Y. 2016. Identification of the type sugar, organic acid, organic acids, minerals, amino acids seed kabau (Archidendron microcarpum) fresh and boil as flavor components. Essay. Food Technology and Agricultural Products. Universitas Gadjah Mada.

Rahmadian, Y., Supriyadi., Santoso, U., Mahmudah, N.A. and Akbar Nur Ichsan, O., 2019. Non-volatile taste components and amino acid profile of jengkol (Pithecellobium jiringa) seed flour after steam blanching. International Journal of Food Properties. 22(1):15361547.

Ribeiro, L.S., Miguel, M.G.D.C.P., Evangelista, S.R., Martins, P.M.M., van Mullem, J., Belizario, M.H. and Schwan, R.F. 2017. Behavior of yeast inoculated during semi-dry coffee fermentation and the effect on chemical and sensorial properties of the final beverage. Food Research International. 92:26-32. https://doi.org/10.1016/j. foodres.2016.12.011.

Specialty Coffee Association of America. 2009. SCAA Protocols: Cupping Specialty Coffee. Specialty Coffee Association of America. 7p.

Specialty Coffee Association of America. 2013. Coffee term from the specialty Coffee Association of America. The Specialty Coffee Event of the Year. Boston, USA.

Silva, C.F. 2014. Microbial activity coffee during fermentation. In: Cocoa and Coffee Fermentations, pp. 368-423. Schwan, RF and Fleet, GH, Eds., CRC Press, Boca Raton, FL.

Wootton, AE. 1974.The dry matter loss from parchment coffee during processing field. In: Proceedings of the "16eme Colloque International sur la Chimie des Caf'es Verts" ASIC Paris, pp 316-324.

Wong, K.H., Abdul Aziz, S. and Mohamed, S. 2008. Sensory aroma from Maillard reaction of individual and combinations of amino acids with glucose in acidic conditions. International journal of food science \& technology. 43(9):1512-1519.

Yusianto and Widyotomo, S. 2013. Quality and flavor profiles of arabica coffee processed by some fermentation treatments: Temperature, containers, and fermentation agents addition. Pelita Perkebunan. 29(3):220-239. 